\title{
Species composition and abundance of solpugids (Arachnida: Solifugae) in ecotopes of the transitional coastal desert of Chile
}

\section{Composición de especies y abundancia de solífugos (Arachnida: Solifugae) en ecotopos del desierto costero transicional de Chile}

\author{
Daniel Eugenio Valdivia ${ }^{\circledR}$, Jaime Pizarro-Araya ${ }^{2}$, Raúl Briones ${ }^{3}$, Andrés A. Ojanguren-Affilastro ${ }^{4}$ and Jorge \\ Cepeda-Pizarro ${ }^{2}$
}

${ }^{1}$ Laboratorio de Aracnología. Departamento de Zoología, Facultad de Ciencias Naturales y Oceanográficas, Universidad de Concepción, Casilla 160-C, Concepción, Chile.

${ }^{2}$ Laboratorio de Entomología Ecológica, Departamento de Biología, Facultad de Ciencias, Universidad de La Serena, Casilla 599, La Serena, Chile. ${ }^{3}$ División Manejo Ecosistémico, Bioforets S.A. - Casilla 70-C, Concepción-Chile.

${ }^{4}$ División Aracnología, Museo Argentino de Ciencias Naturales Bernardino Rivadavia, Avenida Ángel Gallardo 470, 1405 DJR Buenos Aires, Argentina. $\bigotimes$ danielvaldivia@udec.cl

\begin{abstract}
Using pitfall traps, the species composition and abundance of solpugids were studied in several ecotopes of Chile's transitional coastal desert. The study was conducted in the area around Punta de Choros $\left(29^{\circ} 15^{\prime} \mathrm{S}, 71^{\circ} 26^{\prime} \mathrm{W}\right)$ and in Los Choros Archipelago (29³2'S, 67 61'W), in 2005 and 2006. Five species were recorded: Procleobis sp.; Sedna pirata Muma, 1971 (Ammotrechidae); Mummucia sp.; Mummucia variegata (Gervais, 1849) (Mummuciidae); and Ammotrechelis goetschi Roewer, 1934 (Daesiidae). Solpugid abundance was higher on the continent (65\%) than on the islands $(35 \%)$. The ANOSIM used to evaluate any difference in species richness between ecotopes revealed no significant differences $(\mathrm{R}=0.097, p=0.13)$. The similarity dendrogram obtained from the Bray-Curtis matrix indicates that there are 3 groups of ecotopes: steppe, dune, and a miscellaneous group. From the data it is inferred that the diversity and abundance of solpugids in the ecotopes studied may be related to plant structure and to the pedological conditions of the habitat.
\end{abstract}

Key words: arachnids, coastal deserts, epigean arthropods, soil biodiversity, Chile.

Resumen. Mediante trampas de intercepción se estudió la composición específica y la abundancia de solífugos en diversos ecotopos del desierto costero transicional de Chile. El trabajo se llevó a cabo tanto en el sector de Punta de

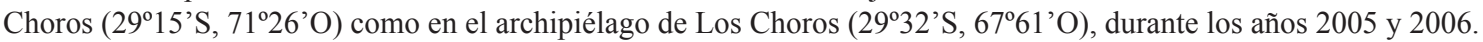
Se registró la presencia de 5 especies: Procleobis sp.; Sedna pirata Muma, 1971 (Ammotrechidae), Mummucia sp.; Mummucia variegata (Gervais, 1849) (Mummuciidae) y Ammotrechelis goetschi Roewer, 1934 (Daesiidae). En el sector continental se observó mayor abundancia que en el sector insular (65\% y 35\%, respectivamente). El ANOSIM aplicado para evaluar la diferencia en la riqueza especifica entre ecotopos, no mostró diferencias significativas $(\mathrm{R}=0.097 ; p=0.13)$. El dendrograma de similitud generado a partir de la matriz Bray-Curtis mostró 3 agrupaciones de ecotopos: estepario, dunario y asociación mixta de ecotopos. De los datos se infiere que la diversidad y abundancia de solpúgidos en los ecotopos estudiados puede estar relacionada con la estructura de la vegetación y con las condiciones pedológicas del hábitat.

Palabras clave: arácnidos, desiertos costeros, artrópodos epígeos, biodiversidad edáfica, Chile.

\section{Introduction}

The order Solifugae is considered a meso-diverse taxon with almost 1100 species described worldwide (Harvey, 2002, 2003; Shultz, 2007). Solpugids inhabit mainly arid and semiarid ecosystems, such as those found in Atacama, Chile (Cepeda-Pizarro et al., 2005); Paracas,

Recibido: 28 abril 2010; aceptado: 02 junio 2011
Peru (Catenazzi et al., 2009); El Monte, Argentina (Flores et al., 2004); and New Mexico, USA (Muma, 1979; Brookhart and Brantley, 2000; Duval and Whitford, 2009). In northern Chile, the ecosystems located in the transitional desert coastal (i.e., $25-32^{\circ}$ Lat S, TDC hereafter) are noteworthy in terms of their biological diversity, endemism, and the prospective conservation of their biota (Rundel et al., 1991; Cepeda-Pizarro et al., 2005). Among the arthropods found in the TDC, only a small number of taxa have attracted researchers' attention. 
For example, the orders of Arachnida that have received the most study are Scorpiones (Ojanguren-Affilastro, 2002; Agusto et al., 2006; Ojanguren-Affilastro et al., 2007) and Acari (Covarrubias et al., 1964, 1976; CepedaPizarro, 1989; Cepeda-Pizarro et al., 1992a, 1992b, 1996). Research on Solifugae, in turn, is limited to 2 contributions, namely Cepeda-Pizarro et al. (2005) who studied the effect of the El Niño Southern Oscillation (ENSO) on the soil-arthropod assemblage and Valdivia et al. (2008) who examined the arthropod density-activity in coastal dunes.

From the point of view of biological diversity and endemism, one of the most important coastal ecosystems of the TDC is the Pingüino de Humboldt National Reserve, formed by the islands of Choros $\left(29^{\circ} 32^{\prime} \mathrm{S}\right.$, $\left.67^{\circ} 61^{\prime} \mathrm{W}\right)$ and Damas $\left(29^{\circ} 13^{\prime} \mathrm{S}, 71^{\circ} 31^{\prime} \mathrm{W}\right)$. These islands, along with Gaviota Island (29 $\left.15^{\prime} \mathrm{S}, 71^{\circ} 28^{\prime} \mathrm{W}\right)$, form the Los Choros Archipelago (Castro and Brignardello, 2005). Most of the available biological knowledge about the archipelago is limited to the avifauna (Luna-Jorquera et al., 2000; Simeone et al., 2003, 2004; Mattern et al., 2004) and vascular plants (Arancio and Jara, 2007). Only recently work has been done on arthropods in this zone (Pizarro-Araya and Flores, 2004; Alfaro et al., 2009). Presently, there is no information on the solpugid fauna of the archipelago so the objectives of this study were (1) to document the species composition of the assemblages of Solifugae found on the above mentioned islands and on the continental land in front of these islands; (2) to document the relative abundance of the species, and (3) to compare the assemblage structure of the island and continental ecotopes.

\section{Materials and methods}

Study area and ecotopes. The study was conducted in the Los Choros archipelago and on the continental area facing it, including the Punta de Choros peninsula and the El Apolillado beach $\left(29^{\circ} 15^{\prime} \mathrm{S}, 7^{\circ} 26^{\prime} \mathrm{W}\right)$ (Fig. 1; Table 1). The study area is located almost $114 \mathrm{~km}$ north of La Serena ( $\left.29^{\circ} 54^{\prime} \mathrm{S}, 71^{\circ} 15^{\prime} \mathrm{W}\right)$. The area has a Mediterranean climate with numerous cloudy days and morning fog (Di Castri and Hajek, 1976). Air temperature is mild, with a narrow temperature range due to the proximity of the Pacific Ocean (Armesto et al., 1993). Dry years (on average less than $25 \mathrm{~mm}$ of annual precipitation) and wet years (more than $175 \mathrm{~mm}$ ) occur in irregular cycles. These cycles are thought to be related to the El Niño Southern Oscillation (ENSO) (Novoa and Villaseca, 1989; Cepeda-Pizarro et al., 2005). In general, the landscape is characterized by a coastal steppe made up of smaller units (ecotopes hereafter) that can be created by the presence of water (e.g., arroyos, small wetlands), or may be pedological in nature (e.g., sand dunes, stony patches), or geomorphologic features (e.g., plains, alluvial fans). The geomorphological details of the study area are described by Castro and Brignardello (2005). Plant characteristics are described by Marticorena et al. (2001) and Arancio and Jara (2007). For this study, 13 sites representing the ecotopes found in the study area were selected. Four sites were located on the continent and the remaining 9 on the islands (Table 1).

Field techniques. Solpugids were collected using pitfall traps set up at the study sites (Table 1$)$ where 2 plots $(4 \times 5$ $\mathrm{m}$ each) were set up. Each plot contained a grid of 20 pitfall traps each separated by $1 \mathrm{~m}$. The trap consisted of

Table 1. Study ecotopes located in the continental and island ecosystems of the transitional coastal desert of Chile

\begin{tabular}{|c|c|c|c|c|}
\hline Ecosystem & Ecotope & Abbreviation & Coordinates & Altitude (m.a.s.l) \\
\hline \multirow{4}{*}{ Continent } & Coastal Steppe & $\mathrm{CS}$ & $29^{\circ} 15^{\prime} \mathrm{S}, 71^{\circ} 26^{\prime} \mathrm{W}$ & 17 \\
\hline & Coastal Dune & $\mathrm{CD}$ & $29^{\circ} 16^{\prime} \mathrm{S}, 71^{\circ} 23^{\prime} \mathrm{W}$ & 18 \\
\hline & Coastal Wetland & $\mathrm{CW}$ & $29^{\circ} 18^{\prime} \mathrm{S}, 71^{\circ} 21^{\prime} \mathrm{W}$ & 2 \\
\hline & Interior Coastal Steppe & ICS & $29^{\circ} 19^{\prime} \mathrm{S}, 71^{\circ} 19^{\prime} \mathrm{W}$ & 23 \\
\hline \multirow{9}{*}{ Archipelago } & Coastal Steppe Choros & $\mathrm{CSCh}$ & $29^{\circ} 32^{\prime} \mathrm{S}, 67^{\circ} 61^{\prime} \mathrm{W}$ & 32 \\
\hline & Interior Stony Choros & IStCh & $29^{\circ} 28^{\prime} \mathrm{S}, 67^{\circ} 59^{\prime} \mathrm{W}$ & 44 \\
\hline & Coastal Stony Choros & $\mathrm{CStCh}$ & $29^{\circ} 29^{\prime} \mathrm{S}, 67^{\circ} 58^{\prime} \mathrm{W}$ & 31 \\
\hline & North Coastal Steppe Damas & NCSD & $29^{\circ} 13^{\prime} \mathrm{S}, 71^{\circ} 31^{\prime} \mathrm{W}$ & 18 \\
\hline & Interior Coastal Steppe Damas & ICSD & $29^{\circ} 14^{\prime} \mathrm{S}, 71^{\circ} 31^{\prime} \mathrm{W}$ & 3 \\
\hline & South Coastal Steppe Damas & SCSD & $29^{\circ} 14^{\prime} \mathrm{S}, 71^{\circ} 31^{\prime} \mathrm{W}$ & 2 \\
\hline & Coastal Dunes Gaviota & $\mathrm{CDG}$ & $29^{\circ} 15^{\prime} \mathrm{S}, 71^{\circ} 28^{\prime} \mathrm{W}$ & 5 \\
\hline & Interior Dunes Gaviota & IDG & $29^{\circ} 15^{\prime} \mathrm{S}, 71^{\circ} 28^{\prime} \mathrm{W}$ & 10 \\
\hline & Coastal Steppe Gaviota & CSG & $29^{\circ} 15^{\prime} \mathrm{S}, 71^{\circ} 26^{\prime} \mathrm{W}$ & 3 \\
\hline
\end{tabular}


a plastic jar filled to two thirds with a preserving liquid as described in Cepeda-Pizarro et al. (2005). Traps were left for 3 days during each of 4 months in 2005 and 2006. The specimens captured were retrieved, cleaned, preserved and stored in the collection of the Laboratorio de Entomología Ecológica of the Universidad de La Serena (LEULS, La Serena, Chile) and in the Laboratorio de Aracnología at the Universidad de Concepción (Concepción, Chile).

Data analysis. Richness and species diversity: Species were identified using Muma (1971) and Maury's works (1977, 1984, and 1987). Maximum-S was estimated using the bootstrapping technique (Manly, 1997) with 1000 iterations with PAST 1.68 computer software (Hammer et al., 2001).

Assemblage structure. The level of structure was determined by applying a non-metric multidimensional scaling ordination analysis (nMDS) (Field et al., 1982; Clarke, 1993) to the Bray-Curtis and Jaccard similarity matrices (Bray and Curtis, 1957). For this analysis the clusters were determined by adjusting convex hull graphs and Kruskal's stress value (Kruskal, 1964; Johnson and Wichern, 1992). To assess the statistical significance of the differences between the sites sampled, a one-way ANOSIM based on the distances of the Bray-Curtis index was used (Clarke, 1993). Significance was evaluated by running 50000 permutations of the observed values. To corroborate the existence of structure, an a posteriori pair-wise ANOSIM tests were conducted, corrected by Bonferroni p-values.

\section{Results}

Species presence and diversity of the Solifugae assemblage. Three hundred and eighty three specimens were captured throughout the study belonging to the families Ammotrechidae (genera Procleobis and Sedna), Daesiidae (genus Ammotrechelis), and Mummuciidae (genus Mummucia). A total of 5 species were collected, 3 of which were identified to the species level (Ammotrechelis goetschi Roewer, 1934; Mummucia variegata (Gervais, 1849), and Sedna pirata Muma, 1971), and 2 to the genus level (Procleobis sp. and Mummucia sp.). All of the species were recorded for the continent, but only 2 of them were found in the archipelago (namely, A. goetschi and $M$. variegata). Diversity was higher in the continental ecotopes than in the insular ones. On the continent, the ecotopes with the highest richness were the steppe type (Table 2). The S-values for all of the sites sampled were lower than expected by chance (Fig. 2).

Relative abundance of the Solifugae assemblage. The continental ecotopes provided the $65 \%$ of the total captures and the insular, 35\%. Among the continental ecotopes, the highest abundance was recorded at the wetland site (37.6\%), while the lowest abundance was recorded for the sand habitat $(5.2 \%)$. In the insular ecotopes, the largest number of captures was made at the interior steppe site (Damas island) (27\% of total captured at the insular sites). In contrast, the smallest number of captures occurred at the stony and coastal steppe sites ( $2.2 \%$ in both cases). On the whole, 2 species numerically dominated the assemblage. These were A. goetschi (43.8\% of total captures) and $M$. variegata (52.5\% of total captures). Whereas abundance of $A$. goetschi was concentrated in the wetland ecotope (93.8\% of total captured in the site), that of $M$. variegata was, in general, evenly distributed. The abundance of the remaining species was quite low and restricted to a few sites (Table 2). For the islands, Choros Island accounted for $14.36 \%$ of the total captures, followed by Damas Island (13.32\%) and Gaviota Island (7.31\%).

Assemblage structure. The ANOSIM found no statistical differences between sampled sites $(\mathrm{R}=0.097 ; p=0.13$; $\mathrm{R}=0.032 ; p=0.63)$. Sites were grouped independently of whether they were continental or insular (Figs. 3 and 4). The similarity dendrogram displayed 3 clusters with a similarity greater than $70 \%$ (Fig. 3). These clusters were (1) a grouping of steppe-type ecotopes (i.e., ICS, ICSD,

Table 2. Richness and relative abundance of Solifugae for ecotopes located in the continental and island ecosystems of the transitional coastal desert of Chile

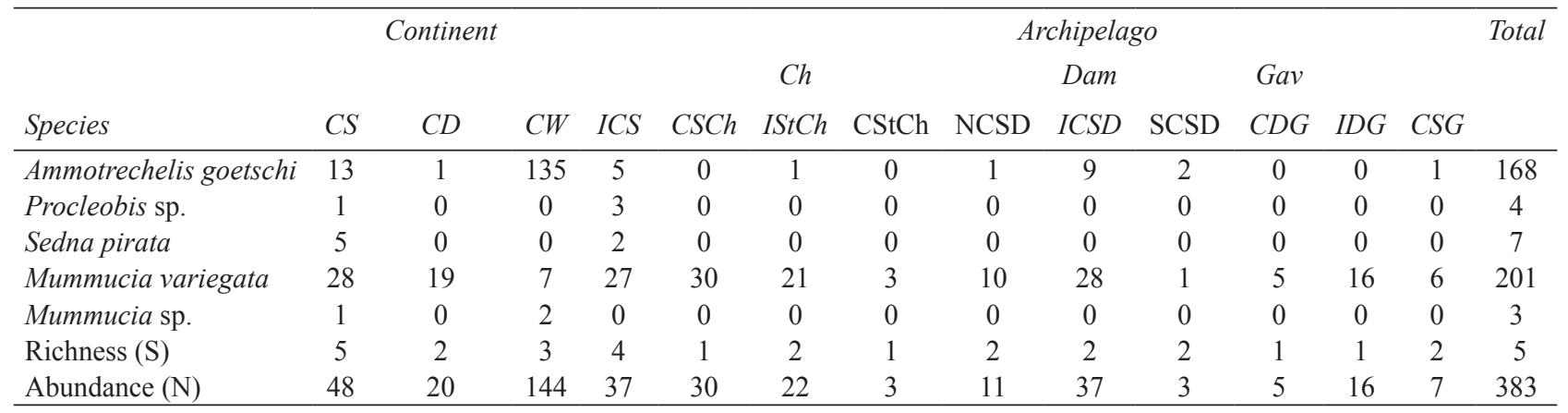




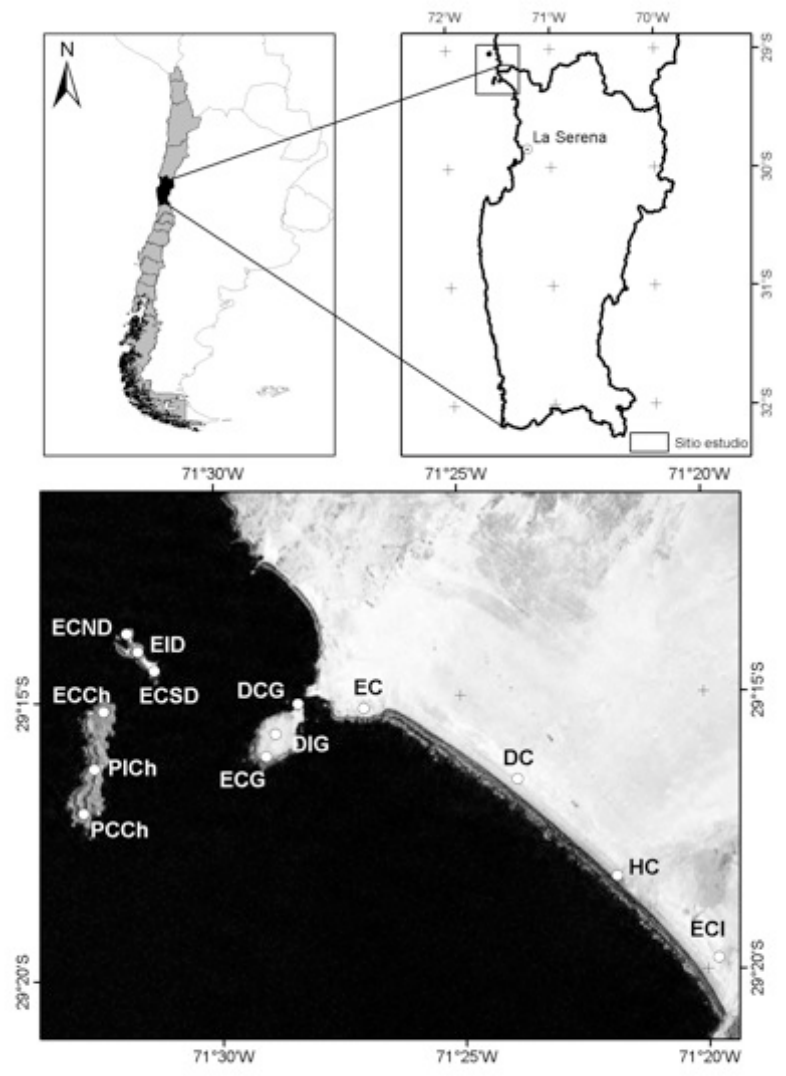

Figure 1. Study area $\left(29^{\circ} 21^{\prime} \mathrm{S}, 71^{\circ} 10^{\prime} \mathrm{W}\right)$. Location of the continental and insular ecotopes studied. CS (Coastal steppe), CD (Coastal Dune), CW (Coastal Wetland), ICS (Interior coastal steppe), CSCh (Coastal steppe Choros), IStCh (Interior stony Choros), CStCh (Coastal stony Choros), NCNSD (North coastal steppe Damas), ICSD (Interior coastal steppe Damas), SCSD (South coastal steppe Damas), CDG (Coastal dunes Gaviota), IDG (Interior Dunes Gaviota), CSG (Coastal steppe Gaviota).
$\mathrm{CS}, \mathrm{CSCh}$ ), (2) a mixed grouping of ecotopes, mainly of the dune type (i.e., NCSD, IDG, CD, IStCh), and (3) a miscellaneous grouping formed by $\mathrm{CStCh}, \mathrm{CDG}$, and CSG. Two units remained at the root of the dendrogram (CEG and CW). The nMDS and the adjustments of the convex hull graphs showed that solpugid diversity is only structured in the steppe ecotopes, with a high degree of overlap of the observed communities among the different sites (e.g., stony and coastal) (Figs. 4A, 4B). The Kruskal stress value showed, in general, a low degree of structure (Fig. 4). The analysis of similarities (ANOSIM) using the Bray-Curtis $(\mathrm{R}=0.6926, p=0.00024)$ and Jaccard indices $(\mathrm{R}=0.4628, p=0.00238)$ showed significant differences among sites, though the paired ANOSIM tests detected no significant differences between pairs of them. Between ecosystems (continent versus insular), the analysis of similarities found no significant differences (Bray-Curtis: $\mathrm{R}=-0.1178, p=0.7859$; Jaccard: $\mathrm{R}=0.03125, p=0.5535$ ).

\section{Discussion}

Although there are reports in the literature supporting the efficiency of pitfall traps as trapping devices for ground arthropods in arid environments (Pietruszka, 1980; Cepeda-Pizarro, 1989; de los Santos et al., 2000, 2002a, 2002b), they do have some limitations that should be kept in mind. For instance, it is well known that capture success depends on the density and activity of the target species, as well as the efficiency of the trap to attract or facilitate their capture and prevent their escape (Gist and Crossley, 1973; Hinds and Rickard, 1973; Adis, 1979). Since no behavioral information exists for individuals of this group, and for the purposes of this study it was assumed that the efficiency of pitfall trapping was equivalent for all the species belonging

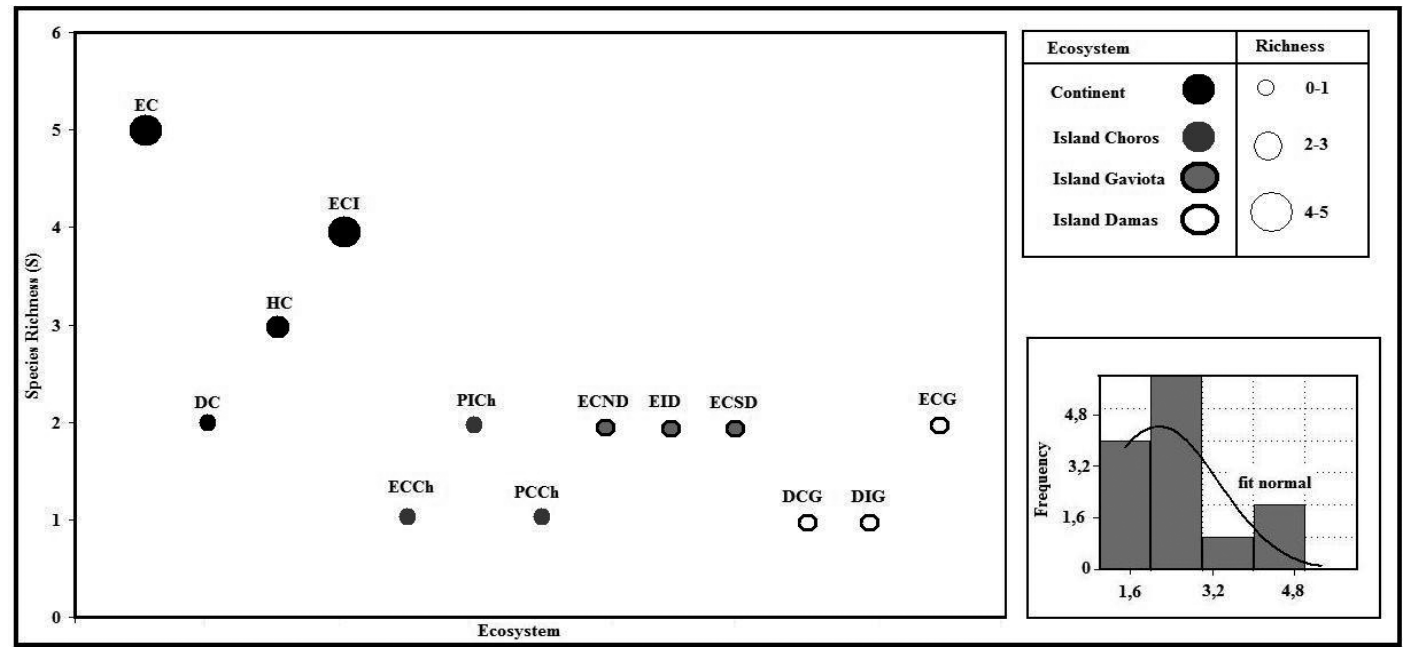

Figure 2. Species richness $(\mathrm{S})$ per ecotope. 


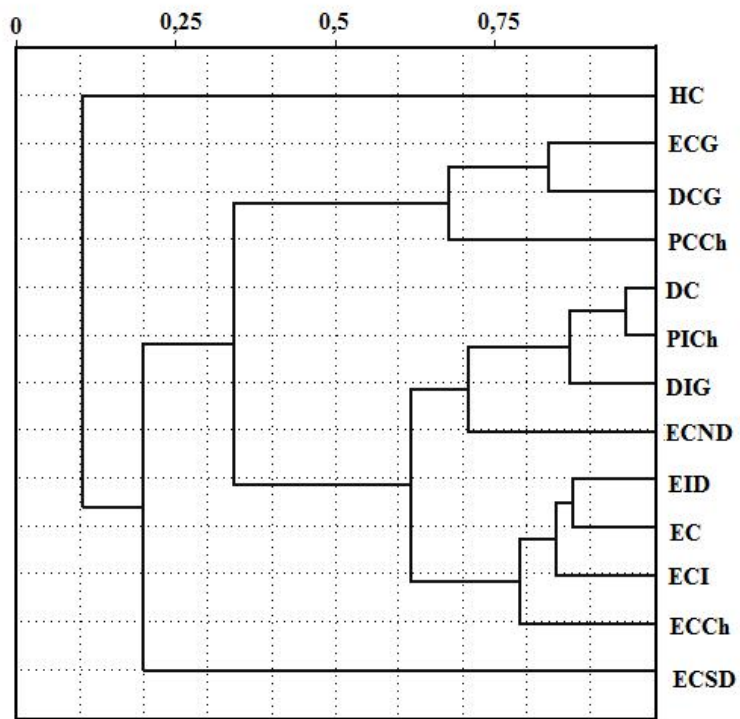

Figure 3. Similarity dendrogram (Bray-Curtis index).

to the assemblage. Any bias was assumed to be minimal, thus sampling reflects species diversity and the abundance of solpugids accordingly.

Species presence and the diversity of the Solifugae assemblage. The southern limit of distribution of $S$. pirata, A. goetschi and $M$. variegata is presently set at $32^{\circ} \mathrm{S}$ (Muma, 1971; Cekalovic, 1975). Therefore, the presence of these species at our study sites is not surprising. For the specimens identified as Muтmucia sp. and Procleobis sp., it is necessary to confirm their identity with further taxonomical analyses, which is beyond the scope of this study. Given that the presence of the genus Muтmисia in the area is represented by M. variegata (Muma, 1971; Cekalovic, 1975), it is probable that Muттисіа sp. is a record of a species new to this area. The genus Procleobis is represented in South America by $P$. patagonicus (Holmerg) from Argentina (Maury, 1977). The specimen of Procleobis captured in this study is the first record for TDC, and it is probably also a new species. Of the 5 species found in this study, 4 of them are restricted to the transitional desert of Chile (Muma, 1971) while $M$. variegata has a broader distribution that includes Peru and Bolivia (Harvey, 2003).

Taking into account the findings in the continental ecotopes, the species diversity of solpugids seems to be related to the vegetation and pedological characteristics of the ecotopes (e.g., steppe type versus dune type ecotopes), in agreement with what has been reported for solpugids from other areas (Valdivia et al., 2008; Xavier and Rocha, 2001) and other arthropod taxa inhabiting arid environments (Goloboff, 1995; Jerez, 2000; Pizarro-
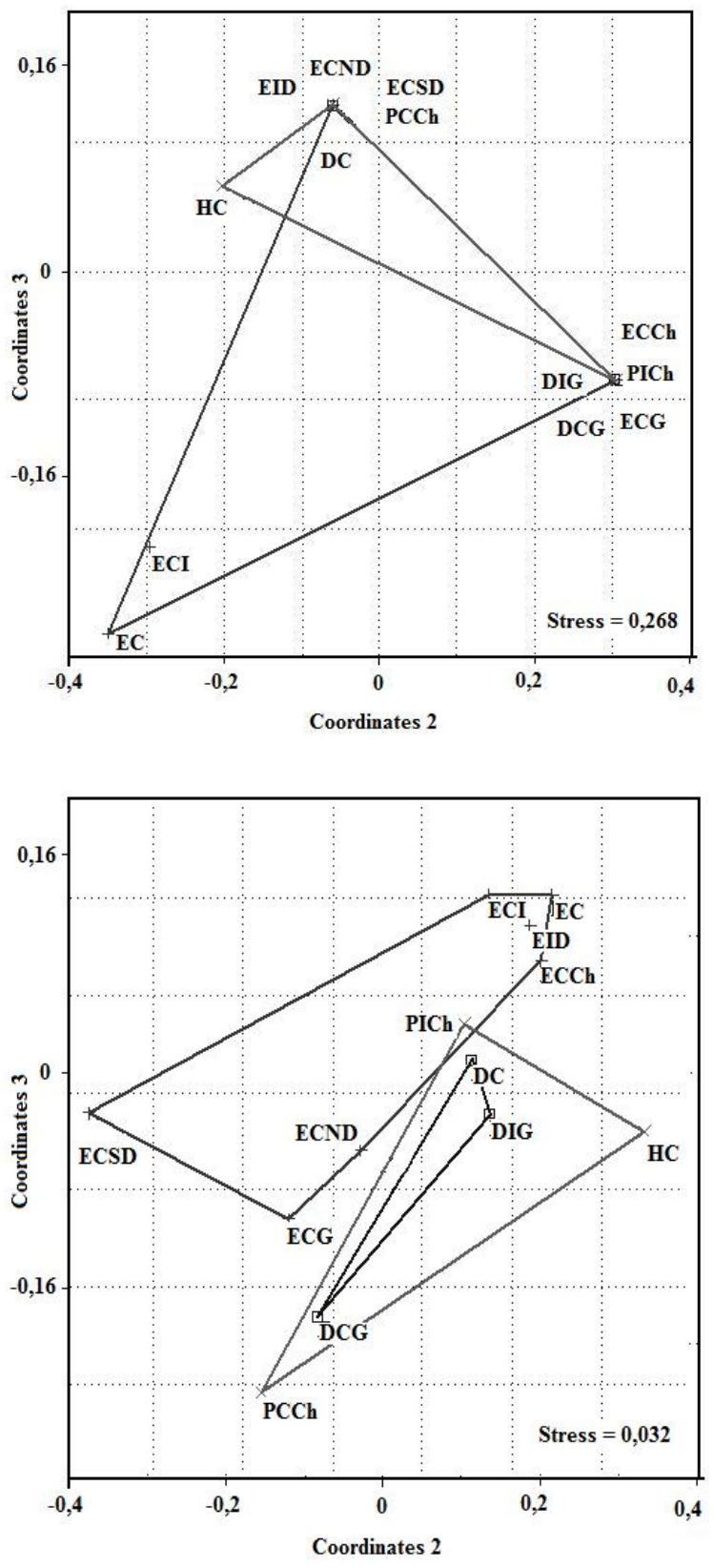

Figure 4. NMDS and Kruskal's stress value. (A): based on the Jaccard similarity index; (B) based on the Bray-Curtis similarity index. The lines enclosing each group are the convex hulls.

Araya and Jerez, 2004; Agusto et al., 2006; Pizarro-Araya et al., 2008). The field observations carried out in this study indicated that this association would be similar to that described for other mummucids and ammontrechids (Crawford, 1988; Rogers et al., 1988; Dean and Griffin, 1993; Brookhart and Brantley, 2000; Xavier and Rocha, 2001). In turn, while some species are apparently less 
restricted in their habitat requirements (e.g., M. variegata), most of them seem to be quite specific (e.g., A. goetschi). Relative abundance of the Solifugae assemblage between ecosystems. The differences observed between the continental and insular ecotopes can be explained by: (1) the level of isolation of the insular systems and the extinction rate (Walter, 2004); and (2) the size of the islands given that they are rather small, ranging in surface area -from 56 ha (Damas Island) to 322 ha. (Choros Island); and (3) man-made pressure. Until recently, the islands were intensively used by local people as fishing areas, guano extraction and to obtain forage for goats. Although 2 of the islands are now protected with restricted human access, they are attractive areas for tourism due to the rich marine fauna that surrounds them, including dolphins and whales (Ribeiro et al., 2007).

Abundance was the greatest in the wetland ecotope and this abundance seems to be related to good shelter and food availability. Although these are small and some are seasonal, wetland sites are quite important in the study area. By offering plant cover for shelter, adequate moisture conditions and food, these sites may favor the presence of invertebrates in an environment that otherwise would be very difficult to colonize. According to previous studies (e.g., Dean and Griffin, 1993; Xavier and Rocha, 2001; Martins et al., 2004; Rocha and Carvalho, 2006), this relationship may be related to the presence of a greater diversity of microhabitats, to a greater abundance of prey or both. On the whole, the insular ecotopes appear to be harsher environments for solpugids than the continental ones. Due to the man-made pressure and island size, the island ecotopes have less protective plant cover and these sites are more exposed to the saline oceanic winds, which are frequently quite strong.

The assemblages were numerically dominated by 2 species (A. goetschi and $M$. variegata). Together they accounted for $96.3 \%$ of the total captures. The distribution of these species among the ecotopes was quite different. Whereas A. goetschi had a rather narrow habitat preference, almost fully restricted to the continental wetland, $M$. variegata was present in both the insular and the continental ecotopes. With few exceptions, the abundance distribution of $M$. variegata was even among ecotopes. From these observations, it is assumed that of the 5 species that make up the solpugid assemblage, $M$. variegata is the most adapted to the prevailing environmental conditions. Since sites were also different with respect to their pedological features (ranging from mobile dunes to sandy or gravelly soil) the data reinforces the idea that the pedological features of the ecotope are also an important factor to the species distribution and abundance of solpugids. For instance, sites with stable sands (e.g., fossil dunes, which are common in the area) or sandy soils such as those of the steppe-type ecotopes, had a higher abundance and diversity than sites with gravelly soils (e.g., reg-type soils) or mobile sands (e.g., erg-type soils). Pedological conditions may affect body hydration, oxygen supply, oviposition, egg-protection, protective excavation, feeding activity, and even skin corrosion (Crawford, 1981; Wallwork, 1982; Dean and Griffin, 1993). For instance, according to Muma (1966a, 1966b), less compact substrates (e.g., sandy soils) facilitate excavation and thus egg and juvenile protection. This may explain the presence of Procleobis sp., Sedna pirata, and Mummucia sp. in the continental ecotopes, where stabilized dunes predominate (Castro and Brignardello, 2005). The insular ecotopes, in addition to offering more exposed sites as mentioned, have pedological conditions that may prevent excavation, especially for large solpugids, thus favoring the smaller species. This may explain the clear numerical dominance of $M$. variegata on the islands. M. variegata is about 0.7 $\mathrm{cm}$ long, compared to $A$. goetschi which is $5 \mathrm{~cm}$ long.

The assemblage structure of solpugids in the area seems to be driven by site exposure, pedological features, and food availability; however, no tight grouping was found. Based on the community analysis data, assemblages would seem to be rather loose. Unfortunately, the literature is lacking in this area and there are no other studies available for comparison. However, this characteristic of the assemblages is not surprising since most of the biological communities studied in deserts exhibit this configuration (Shmida et al., 1986; Polis, 1991).

\section{Acknowledgements}

We are grateful to Mark S. Harvey (Department of Terrestrial Invertebrates, Western Australian Museum, Australia), Alexander V. Gromov (Laboratory of Entomology, Institute of Zoologypor, Kazakhstan), and Richard Dean (Percy FitzPatrick Institute of African Ornithology, University of Cape Town, South Africa) for providing bibliographical material, and Luis Letelier (Departamento de Biología, Universidad de La Serena, Chile) for GIS assistance and GPS data. We thank Antonio de los Santos Gómez (Departamento de Ecología, Universidad de Laguna, Spain) for feedback on the manuscript. We also thank the members of the Systematics of Solpugids project, NSF, BSI, Grants 0640219 and 0640245 (on which the authors are external collaborators), for their support with bibliographical material. This research was funded by projects FPA-04007-2005 and FPA-04-015-2006 (CONAMA, Coquimbo Region, Chile), DIULS-PF07101 of the Universidad de La Serena, La Serena, Chile (J.P.A.). This study is part 
of the "Ecology and taxonomic diversity of arthropods and vertebrates of the transitional coastal desert of Chile" program (Departamento de Biología, Universidad de La Serena, Chile).

\section{Literature cited}

Adis, J. 1979. Problems of interpreting arthropod sampling with pitfall traps. Zoologischer Anzeiger 202:177-184.

Agusto, P., C. I. Mattoni, J. Pizarro-Araya, J. Cepeda-Pizarro and F. López-Cortés. 2006. Comunidades de escorpiones (Arachnida: Scorpiones) del desierto costero transicional de Chile. Revista Chilena de Historia Natural 79:407-421.

Alfaro, F. M., J. Pizarro-Araya and G. E. Flores. 2009. Epigean tenebrionids (Coleoptera: Tenebrionidae) from the Choros Archipelago (Coquimbo Region, Chile). Entomological News 120:125-130.

Arancio, G. and P. Jara. 2007. Flora de la Reserva Nacional Pingüino de Humboldt. Ediciones Universidad de La Serena, La Serena, Chile. 71 p.

Armesto, J. J., P. E. Vidiella and J. R. Gutiérrez. 1993. Plant strategies in the Chilean coastal desert. Revista Chilena de Historia Natural 66:271-282.

Bray, R. J. and J. L. Curtis. 1957. An ordination of the upland forest communities of southern Wisconsin. Ecological Monographs 27:325-349.

Brookhart, J. O. and S. L. Brantley. 2000. Solpugids (Arachnida) of the Sevilleta National Wildlife Refuge, New Mexico. Southwestern Naturalist 45:443-449.

Castro, C. and L. Brignardello. 2005. Geomorfología aplicada a la ordenación territorial de litorales arenosos. Orientaciones para la protección, usos y aprovechamiento sustentables del sector de Los Choros, Comuna de la Higuera, IV Región. Revista de Geografía Norte Grande (Chile) 33:33-58.

Catenazzi, A., J. O. Brookhart and P. E. Cushing. 2009. Natural history of coastal Peruvian solifuges with a redescription of Chinchippus peruvianus and an additional new species (Arachnida, Solifugae, Ammotrechidae). Journal of Arachnology 37:151-159.

Cekalovic, T. 1975. Catálogo sistemático de los Solifugae de Chile (Arachnida). Boletín de la Sociedad de Biología de Concepción (Chile) XLIX:131-137.

Cepeda-Pizarro, J. 1989. The relationships between abiotic factors and the abundance patterns of soil microarthropods on a desert watershed. Pedobiologia 33:76-86.

Cepeda-Pizarro, J., J. Pizarro-Araya and H. Vásquez. 2005. Composición y abundancia de artrópodos epígeos del Parque Nacional Llanos de Challe: impactos del ENOS de 1997 y efectos del hábitat pedológico. Revista Chilena de Historia Natural 78:635-650.

Cepeda-Pizarro, J., J. R. Gutiérrez, L. Valderrama and H. Vásquez. 1996. Phenology of the edaphic microarthropods in a Chilean coastal desert site and their response to water and nutrient amendments in the soil. Pedobiologia 40:352-363.

Cepeda-Pizarro, J., M. A. Rojas, M. B. Maldonado, J. Vilches and N. Pereira. 1992a. Effect of season, substrate quality, litter quality and soil conditions on edaphic microarthropods in a coastal desert site of north-central Chile. Revista Chilena de Historia Natural 65:65-74.

Cepeda-Pizarro, J., M. A. Rojas, M. B. Maldonado, J. Vilches and N. Pereira. 1992b. A litter-bag study of mite densities (Actinedida and Oribatida) in Atriplex litter and soil of a desert site in northern Chile. Journal of Arid Environments 23:177-188.

Clarke, A. E. 1993. Vertical disintegration and spatial aspects of production subcontracting. Abstracts of the Association of American Geographers 1993 Annual Meeting, Atlanta, USA.

Covarrubias, R., I. Rubio and F. Di Castri. 1964. Observaciones ecológico-cuantitativas sobre la fauna edáfica de zonas semiáridas del Norte Chico de Chile. Boletín de Producción Animal (Chile) Serie A:1-109.

Covarrubias, R., I. Rubio and F. Di Castri. 1976. Densidad edáfica en comunidades naturales e intervenidas del Norte Chico de Chile. Investigaciones Zoológicas Chilenas 14:15-23.

Crawford, C. S. 1981. Biology of desert invertebrates. SpringerVerlag. New York. 314 p.

Crawford, C. S. 1988. Surface-active arthropods in a desert landscape: influences of microclimate, vegetation, and soil surface on assemblage structure. Pedobiologia 32:373-385.

de los Santos, A., J. P. de Nicolas and F. Ferrer. 2002a. Habitat selection and assemblage structure of darkling beetles (Col. Tenebrionidae) along environmental gradients on the island of Tenerife (Canary Islands). Journal of Arid Environments 52:63-85.

de los Santos, A., E. J. Alonso, E. Hernandez and A. M. Perez. 2002b. Environmental correlates of darkling beetle population size (Col. Tenebrionidae) on the Cañadas of Teide in Tenerife (Canary Islands). Journal of Arid Environments 50:287-308.

de los Santos, A., L. A. Gómez-González, C. Alonso, C. D. Arbelo and J. P. de Nicolás. 2000. Adaptative trends of darkling beetles (Col. Tenebrionidae) on environmental gradients on the island of Tenerife (Canary Islands). Journal of Arid Environments 45:85-98.

Dean, W. R. J. and E. Griffin. 1993. Seasonal activity patterns and habitats in Solifugae (Arachnida) in the southern Karoo, South Africa. South African Journal of Zoology 28:91-94.

Di Castri, F. and E. R. Hajek. 1976. Bioclimatología de Chile. Imprenta-Editorial de la Universidad Católica de Chile. Santiago, Chile. 129 p.

Duval, B. D. and W. G. Whitford. 2009. Camel spider (Solifugae) use of prairie dog colonies. Western North American Naturalist 69:272-276.

Field, J. G., K. Clarke and R. Warwick. 1982. A practical strategy 
for analyzing multispecies distributions. Marine Ecology Progress Series 8:37-52.

Flores, G. E., S. J. Lagos and S. Roig-Juñent. 2004. Artrópodos epígeos que viven bajo la copa del algarrobo (Prosopis flexuosa) en la Reserva Telteca (Mendoza, Argentina). Multequina (Argentina) 13:71-90.

Gist, C. and D. A. Crossley. 1973. A method for quantifying pitfall trapping. Environmental Entomology 2:951-952.

Goloboff, P. A. 1995. A revision of the South American spiders of the family Nemesiidae (Araneae, Mygalomorphae). Part I: Species from Peru, Chile, Argentina, and Uruguay. Bulletin of the American Museum of Natural History 224:1-189.

Hammer, Ø., D. A. T. Harper and P. D. Ryan. 2001. PAST: Palaeontological Statistics Software Package for Education and Data Analysis. Paleontología Electrónica 4:1-9.

Harvey, M. S. 2002. The neglected cousins: What do we know about the smaller Arachnid orders? Journal of Arachnology 30:357-372.

Harvey, M. S. 2003. Catalogue of the Smaller Arachnid Orders of the World. Amblypygi, Uropygi, Schizomida, Palpigradi, Riciniculei and Solifugae. CSIRO Publishing, Collingwood, Victoria, Australia. 385 p.

Hinds, W. T. and W. H. Rickard. 1973. Correlations between climatological fluctuations and a population of Philolithus densicollis (Horn) (Coleoptera: Tenebrionidae). Journal of Animal Ecology 42:341-351.

Jerez, V. 2000. Diversidad y patrones de distribución geográfica de insectos coleópteros en ecosistemas desérticos de la región de Antofagasta, Chile. Revista Chilena de Historia Natural 73:79-92.

Johnson, R. and D. Wichern. 1992. Applied multivariate statistical analysis. Prentice Hall, New York, USA. 642 p.

Kruskal, J. B. 1964. Multidimensional scaling by optimizing goodness of fit to a nonmetric hypothesis. Psychometrika 29:1-27.

Luna-Jorquera, G., S. Garthe, F. G. Sepúlveda, T. Weichler and J. A. Vásquez. 2000. Population size of Humboldt Penguins assessed by combined terrestrial and at-sea counts. Waterbirds 23:506-510.

Manly, B. F. J. 1997. Randomization, Bootstrap and Monte Carlo methods in Biology. 2nd edition. Chapman and Hall, London, UK. 424 p.

Marticorena, C., F. A. Squeo, G. Arancio and M. Muñoz. 2001. Catálogo de la flora vascular de la IV Región de Coquimbo. In Libro Rojo de la Flora Nativa y de los Sitios Prioritarios para su Conservación. Región de Coquimbo, F. A. Squeo, G. Arancio and J. R. Gutiérrez (eds.). Ediciones de la Universidad de La Serena, La Serena, Chile. p. 105-142.

Martins, E. G., V. Bonato, G. Machado, R. Pinto-Da Rocha and L. S. Rocha. 2004. Description and ecology of a new species of sun spider (Arachnida: Solifugae) from the Brazilian Cerrado. Journal of Natural History 38:2361-2375.
Mattern, T., U. Ellenberg, G. Luna-Jorquera and D. Lloyd. 2004. Humboldt Penguin census on Isla Chañaral, Chile: Recent increase or past underestimate of penguin numbers? Waterbirds 27:368-376.

Maury, E. A. 1977. Notas sobre la sistemática y distribución geográfica de Procleobis patagonicus (Holmberg, 1876) (Solifugae, Ammotrechidae, Saronominae). Physis, Sección C (Argentina) 36:283-293.

Maury, E. A. 1984. Las familias de solífugos americanos y su distribución geográfica (Arachnida, Solifugae). Physis, Sección C (Argentina) 42:73-80.

Maury, E. A. 1987. Consideraciones sobre algunos solífugos de Chile (Solifugae: Ammotrechidae, Daesiidae). Revista de la Sociedad Entomológica Argentina 44:419-432.

Muma, M. H. 1966a. Egg deposition and incubation for Eremobates durangonus with notes on the eggs of other species of Eremobatidae (Arachnida: Solpugida). Florida Entomologist 49:23-31.

Muma, M. H. 1966b. Burrowing habits of North American Solpugida (Arachnida). Psyche 73:251-260.

Muma, M. H. 1971. The Solpugids (Arachnida, Solpugida) of Chile, with descriptions of a new family, new genera, and new species. American Museum Novitates 2476:1-23.

Muma, M. H. 1979. Arid-grassland solpugid population variations in southwestern New Mexico. Florida Entomologist 62:320-328.

Novoa, R. and S. Villaseca. 1989. Mapa agroclimático de Chile. Instituto de Investigaciones Agropecuarias, Santiago, Chile. $221 \mathrm{p}$.

Ojanguren-Affilastro, A. A. 2002. Nuevos aportes al conocimiento del género Brachistosternus en Chile, con la descripción de dos nuevas especies (Scorpiones, Bothriuridae). Boletín de la Sociedad de Biología de Concepción (Chile) 73:37-46.

Ojanguren-Affilastro, A. A., P. Agusto, J. Pizarro-Araya and C. I. Mattoni. 2007. Two new scorpion species of genus Brachistosternus (Scorpiones: Bothriuridae) from northern Chile. Zootaxa 1623:55-68.

Pietruszka, R. D. 1980. Observations on seasonal variation in desert arthropods in central Nevada. Great Basin Naturalist 40:292-297.

Pizarro-Araya, J. and G. E. Flores. 2004. Two new species of Gyriosomus Guérin-Méneville from Chilean coastal desert (Coleoptera: Tenebrionidae: Nycteliini). Journal of the New York Entomological Society 112:121-126.

Pizarro-Araya, J. and V. Jerez. 2004. Distribución geográfica del género Gyriosomus Guérin-Méneville, 1834 (Coleoptera: Tenebrionidae): Una aproximación biogeográfica. Revista Chilena de Historia Natural 77:491-500.

Pizarro-Araya, J., J. Cepeda-Pizarro and G. E. Flores. 2008. Diversidad taxonómica de los artrópodos epígeos de la Región de Atacama (Chile): estado del conocimiento. In Libro Rojo de la Flora Nativa y de los Sitios Prioritarios 
para su Conservación: Región de Atacama, F. A. Squeo, G. Arancio and J. R. Gutiérrez (eds.). Ediciones Universidad de La Serena, La Serena. Chile. p. 257-274.

Polis, G. A. 1991. (ed.). The ecology of desert communities. The University of Arizona Press. Arizona. $456 \mathrm{p}$.

Ribeiro S., F. A. Viddi, J. K. Cordeiro and T. R. O. Freitas. 2007. Fine-scale habitat selection of Chilean dolphins (Cephalorhynchus eutropia): interactions with aquaculture activities in southern Chiloe Island, Chile. Journal of the Marine Biological Association of the United Kingdom 87:119-128.

Rocha, L. S. and M. C. Carvalho. 2006. Description and ecology of a new solifuge from Brazilian Amazonia (Arachnida, Solifugae, Mummuciidae). Journal of Arachnology 34:163-169.

Rogers, L. E., N. E. Woodley, J. K. Sheldon and P. A. Beedlow. 1988. Diets of darkling beetles (Coleoptera: Tenebrionidae) within a shrub-steppe ecosystem. Annals of the Entomological Society of America 81:782-791.

Rundel, P. W., M. O. Dillon, B. Palma, H. A. Mooney, S. L. Gulmon and J. R. Ehleringer. 1991. The phytogeography and ecology of the coastal Atacama and Peruvian deserts. Aliso 13:1-49.

Shmida, A., M. Evanaria and I. Noy-Meir. 1986. Hot desert ecosystems: an integrated view. In Hot deserts and arid shrublands B. Ecosystems of the World 12b. Chapter 10, M. Evanari, I. Noy-Meir and F. W. Goodwall (eds.). Elsevier
New York. p. 379-387.

Shultz, J. W. 2007. A phylogenetic analysis of the arachnid orders based on morphological characters. Zoological Journal of the Linnean Society 150:221-265.

Simeone, A., G. Luna-Jorquera and R. P. Wilson. 2004. Seasonal variations in the behavioural thermoregulation of roosting. Journal Ornithology 145:35-40.

Simeone, A., G. Luna-Jorquera, M. Bernal, S. Garthe, F. Sepúlveda, R. Villablanca, U. Ellenberg, M. Contreras, J. Muñoz and T. Ponce 2003. Breeding distribution and abundance of seabirds on island off north-central Chile. Revista Chilena de Historia Natural 76:323-333.

Valdivia, D. E., J. Pizarro-Araya, J. Cepeda-Pizarro and A. A. Ojanguren-Affilastro. 2008. Diversidad taxonómica y densoactividad de solífugos (Arachnida: Solifugae) asociados a un ecosistema desértico costero del centro norte de Chile. Revista de la Sociedad Entomológica Argentina 67:1-10.

Wallwork, J. A. 1982. Desert soil fauna. Westfield College. Univeristy of London. Praeger Special Studies. Praeger Scientific. New York. 296 p.

Walter, H. S. 2004. The mismeasure of islands: implications for biogeographical theory and the conservation of nature. Journal of Biogeography 31:177-197.

Xavier, E. and L. S. Rocha. 2001. Autoecology and description of Mummucia mauryi (Solifugae, Mummuciidae), a new solifuge from Brazilian semi-arid Caatinga. Journal of Arachnology 29:127-134. 